\title{
THE IMPACT OF THE ABOLITION OF TAX CREDIT ON EX-DIVIDEND DAY ABNORMAL RETURNS IN THE UNITED KINGDOM (UK) MARKET
}

\author{
HardoBasuki
}

The ex-dividend day returns are composed of the capital gains component and the dividends component. This study mainly examines the relationship between the 1997 abolition of the tax-credit and the ex-dividend day abnormal stock returns in the UK market (London Stock Exchange). The 1997 abolition of the tax credit on dividend effectively reduced the income of pension funds and other tax-exempt shareholders who had a strong preference for dividends. This study finds that the ex-day abnormal returns (AR) declined from +0.0580 percent during the pre-abolition periods to -0.1459 percent during the post-abolition periods. This decline is statistically significant with a t-value of 2.0431. From these results it would appear that the ex-dividend day AR changed following the 1997 abolition of tax credits on dividends.

Moreover the comparison tests of ex-day drop-off ratios between pre-and post-abolition periods show that drop-off ratios for all dividend yield groups increased significantly from 0.519 in the preabolition periods to 0.574 over the post-abolition periods with a $\mathrm{t}$ value of 2.183. Thus, the decrease on ex-day AR was further supported by a significant increase in the average price-drop to dividend ratios.

The decline in the ex-day AR for the post-abolition periods seems to be driven primarily by quintile 5 (the highest dividendyield quintile). Quintile 5 exhibits strong dividend preference and this 
Gadjah Mada InternationalJournal of Business, May-August 2006, Vol. 8, No. 2

preference is likely caused by the imputation system that provides a tax advantage to the tax exempt shareholders. This finding appears to suggest that the highest dividend yield securities are likely to be held by tax-exempt investors such as pension funds that were affected by the abolition of the tax credits on dividend.

Keywords: abnormal stock returns; abolition of tax credit; drop-off ratio; exdividend day

\section{Introduction}

In July 1997 a major change in the tax arrangements relating to dividends was introduced by the British government. The government abolished the tax-credit on the net dividends received by pension funds and other tax exempt institutional shareholders. In his budget speech of 2 July 1997, Mr. Gordon Brown, the Chancellor of the Exchequer, stated:

"The present system of tax-credits encourages companies to pay out dividends rather than reinvest their profits. This cannot be the best way of encouraging investment for the long term as was acknowledged by the last government. Many pension funds are in substantial surplus and at present many companies are enjoying pension holidays, so this is the right time to undertake longneeded reform. So, with immediate effect, Ipropose to abolish tax credits paid to pension funds and companies." [Brown 1997. Budget statement. HANSARD-Parliamentary Debate, House of Commons Official Report 297 (33): 306].
Pension Funds are tax-exempt and prior to the change they received a refund (tax credits) on their dividend incomes. The tax credits did, of course, reduce the tax revenues of the UK (United Kingdom) government as they effectively represented a refund to shareholders of part of companies' corporation tax. The 'imputation system' provided a tax advantage to the pension funds and other tax exempt shareholders which may have encouraged dividend payments at the expense of reinvested funds.

For any dividends paid on or after 2 July 1997, pension providers and most UK corporate shareholders (including authorised unit trusts) would no longer be entitled to payment of the related tax credit. The UK government also eliminated ACT (advance corporation tax) refunds for other zero-rate taxpayers starting in 1999. However, tax credits were to continue for charities and some other tax exempt institutions until 1999 when they were proposed to be gradually eliminated over a period of five years. Another government's proposal would reduce the rate of the tax credit for other 
shareholders from 20 percent to 10 percent in 1999. At the same time, the government proposed decreasing the corporate tax rate from 33 percent to 31 percent.

Bond et al. (1995) claim that the imputation tax system had introduced some distortions that were likely to have some effect on the level of dividend payments by UK companies. Following the introduction of the imputation system in 1973, many companies responded by substantially increasing their dividends. Tax-exempt investors such as pension funds are the most influential stockholders in many UK companies and their tax preference for dividends may have instigated the higher dividend payments.

The 1997 abolition of the tax credit on dividend aimed to remove a perceived distortion in the tax system that encouraged the distribution of earnings as dividends rather than their retention for investment purposes. High dividend payouts may reduce the availability of a relatively low-cost internal source of funds, and this could decrease the level of investment expenditures. Hence, the UK government attempted to use the tax system to try to encourage lower dividends and larger reinvestment of corporate earnings. At the same time, the removal of the tax credit would substantially increase government's tax revenues.

Since institutional investors are relatively less taxed than individual investors, dividends induce ownership clientele effects. Tax exempt institutions such as pension funds and charities are the primary shareholders of dividend-paying firms. Allen et al. (2000) re-examined the importance of tax clienteles on a firm's dividend policy in light of the increasing number of tax-exempt institutional investor in the market. One reason for these institutions to hold dividend-paying shares is the restrictions such as 'prudent man rule' that make it more difficult for many institutions to buy shares with low dividends or no dividends. Companies are keen to attract institutional investors to their equity and institutional investors will become the corresponding marginal investors in such shares.

In the UK market, before the 1997 tax reform institutional investors benefited from a tax credit, thus further encouraging them to seek out high dividend payout firms to invest in. According to Allen et al. (2000), institutional investors can use their block holdings to influence corporate decisions and increase or maintain the dividend payment in their favor. Since the tax-exempt investors are the most significant investors in many UK companies, their tax preference for dividends may have had an important impact on corporate dividend policy. Motivated by the theory of dividends developed by Allen et al. this examines the impact of the 1997 tax change on corporate dividend policy and by so doing is also able to assess the influence of the institutional investors. 
In addition, the traditional differential taxation of dividends and capital gains has generated controversy with regard to valuation of the firm's equity and the setting of the firm's dividend policy. If corporate managers perceive investors to have tax-induced preferences that may influence the valuation of equity, then changes in the effective taxation of dividends and/or capital gains should affect corporate dividend policy. The 1997 abolition of tax-credit on dividends to taxexempt institutions provides a clear opportunity to test whether taxes affect corporate dividend policy.

\section{The Taxation of Dividends in the United Kingdom (UK)}

From 1973 to 1997 the UK government operated an imputation tax system of corporation tax under which some tax relief on dividend income was provided to all stockholders in recognition of corporation tax paid by the company. In effect, part of corporation tax counted as the basic rate of income tax on dividends paid to shareholders.

Under the imputation system, corporation tax is payable in two installments. The first payment, Advance Corporation Tax (ACT), is made soon after the companies pay their dividends and is based on the amount of the dividends paid. This is treated as income tax on the dividends paid, hence the recipients of the dividends receive a tax credit. The rate of ACT was set equal to basic rate of income tax from 1973, and then the lower band rate of income tax from 1994. For example, in 1998, advance corporation tax (ACT) was paid at a rate of 20 percent on the notional gross dividend received by a shareholder. The second payment of corporate tax, Mainstream Corporation Tax (MCT), is payable approximately 9 months after the end of the firm's accounting period. The company subtracts the ACT (the first payment) from its total corporation tax liability, and pays the difference in MCT.

Therefore, under the imputation system, the dividend comes with a tax credit. A basic rate tax payer in receipt of dividends is deemed to have paid the income tax due, i.e. the ACT counts as basic rate income tax paid. A higher tax rate payer is required to pay the difference between higher rate tax and basic rate tax (lower band rate from 1994) on all dividends received. Tax exempt shareholders receive a tax refund equal to the tax credit. The significant change in 1997 meant that some tax exempt shareholders would no longer receive this 'tax refund.'

Table 1 shows the income tax rates in the UK from 1987. In 1988, the UK government abolished all rates of income tax above 40 percent, taking the top rate from 60 percent to 40 percent. 
Basuki-The Impact of the Abolition of Tax Credit on ...

Table 1. UK Corporate Tax Rates, Dividend Income Tax Rates and

\begin{tabular}{|c|c|c|c|c|c|}
\hline \multirow[b]{2}{*}{ Year } & \multirow{2}{*}{$\begin{array}{c}\text { Corporate } \\
\text { Tax Rate } \\
\left(\mathbf{t}_{\mathrm{c}}\right)\end{array}$} & \multicolumn{3}{|c|}{ Tax Credit Rates (1987-1999) } & \multirow{2}{*}{$\begin{array}{c}\text { Tax Credit } \\
\text { Rate } \\
\text { (s) }\end{array}$} \\
\hline & & $\begin{array}{l}\text { Lower Rate* } \\
\text { (Basic Rate) }\end{array}$ & Top Rate & Exempt & \\
\hline 1987 & 35 percent & 27 percent & 60 percent & 0 percent & 27 percent \\
\hline 1988 & 35 percent & 25 percent & 40 percent & 0 percent & 25 percent \\
\hline 1989 & 35 percent & 25 percent & 40 percent & 0 percent & 25 percent \\
\hline 1990 & 35 percent & 25 percent & 40 percent & 0 percent & 25 percent \\
\hline 1991 & 33 percent & 25 percent & 40 percent & 0 percent & 25 percent \\
\hline 1992 & 33 percent & 25 percent & 40 percent & 0 percent & 25 percent \\
\hline 1993 & 33 percent & 25 percent & 40 percent & 0 percent & 25 percent \\
\hline 1994 & 33 percent & 20 percent & 40 percent & 0 percent & 20 percent \\
\hline 1995 & 33 percent & 20 percent & 40 percent & 0 percent & 20 percent \\
\hline 1996 & 33 percent & 20 percent & 40 percent & 0 percent & 20 percent \\
\hline 1997 & 31 percent & 20 percent & 40 percent & 0 percent & 20 percent \\
\hline 1998 & 31 percent & 20 percent & 40 percent & 0 percent & 20 percent \\
\hline 1999 & 30 percent & 10 percent & 33 percent & 0 percent & 10 percent \\
\hline
\end{tabular}

* The rate of ACT was set equal to lower band rate from 1994 (previously basic rate).

Table 2. Comparison of Dividend Income Under the Imputation Tax System and the Classical Tax System

\begin{tabular}{|c|c|c|c|c|c|c|c|}
\hline \multicolumn{4}{|c|}{$\begin{array}{l}\text { Dividend Income that would be received } \\
\text { by shareholders under } \\
\text { the IMPUTATION SYSTEM (s=20 percent) }\end{array}$} & \multicolumn{4}{|c|}{$\begin{array}{l}\text { Dividend Income that would be received } \\
\text { by shareholders under } \\
\text { the CLASSICAL SYSTEM }\end{array}$} \\
\hline \multicolumn{4}{|c|}{$£ 1000 *\left(1-t_{C}\right) *(1-m) /(1-s)$} & \multicolumn{4}{|c|}{$£ 1000 *\left(1-t_{C}\right) *(1-m)$} \\
\hline Year & $\begin{array}{c}\text { Basic } \\
\text { Rate } \\
\mathbf{m}=\mathbf{2 0} \\
\text { percent }\end{array}$ & $\begin{array}{c}\text { Top } \\
\text { Rate } \\
\text { m=40 } \\
\text { percent }\end{array}$ & $\begin{array}{c}\text { Exempt } \\
m=0 \\
\text { percent }\end{array}$ & Year & $\begin{array}{c}\text { Basic } \\
\text { Rate } \\
\mathbf{m}=\mathbf{2 0} \\
\text { percent }\end{array}$ & $\begin{array}{c}\text { Top } \\
\text { Rate } \\
\text { m=40 } \\
\text { percent }\end{array}$ & $\begin{array}{c}\text { Exempt } \\
m=0 \\
\text { percent }\end{array}$ \\
\hline $\begin{array}{c}1996 \\
\left(\mathrm{t}_{\mathrm{C}}=33\right. \\
\text { percent })\end{array}$ & $£ 670.0$ & $£ 502.5$ & $£ 837.5$ & $\begin{array}{c}1996 \\
\left(t_{C}=33\right. \\
\text { percent })\end{array}$ & $£ 536.0$ & $£ 402.0$ & $£ 670.0$ \\
\hline $\begin{array}{c}1997 \\
\left(t_{C}=31\right. \\
\text { percent })\end{array}$ & $£ 690.0$ & $£ 517.5$ & $£ 862.5$ & $\begin{array}{c}1997 \\
\left(\mathrm{t}_{\mathrm{c}}=31\right. \\
\text { percent })\end{array}$ & $£ 552.0$ & $£ 414.0$ & $£ 690.0$ \\
\hline
\end{tabular}


Gadjah Mada InternationalJournal of Business, May-August 2006, Vol. 8, No. 2

The basic rate of income tax was cut from 30 percent to 29 percent in 1986, then to 27 percent in 1987 and to 25 percent in 1988. In 1993, the Conservative government cut the tax credit (ACT) from 25 percent to 20 percent. In 1997, the Labor government planned to reduce the tax credit rate from 20 percent to 10 percent starting in 1999 , while abolishing it altogether with immediate effect for tax-exempt financial institutions and corporations. The government also reduced the top corporate tax rate to 31 percent in 1997.

Table 2 compares the dividend income received by shareholders under the imputation tax system, and that which would be received under a classical system of corporate taxes. Suppose a company has $£ 1,000$ of pre-tax profits to be distributed as dividends.

Under the classical system, the net dividend income for shareholders is:

$$
£ 1,000\left(1-t_{\mathrm{C}}\right)(1-\mathrm{m})
$$

where $t_{C}=$ the rate of corporation tax and, $m=$ the shareholder's rate of income tax.

Hence, the company pays corporation tax at the rate $t_{C}$, and the remainder is paid in dividends on which the shareholder pays income tax on at the rate, $m$. In 1996, therefore, with a rate of corporation tax of 33 percent, taxexempt shareholders (e.g., pension funds) would receive net dividend income after all taxes of $£ 670[=£ 1,000 *$ $(1-0.33) *(1-0$ percent $)]$.
Under the UK imputation system, the firm decides on a net dividend to be paid out to the shareholders. The firm pays ACT on a 'notional' gross dividend, and this counts as income tax paid by the shareholders. The gross dividend is simply the net dividend grossed up by the amount of ACT. The net dividend received by shareholders is accompanied with a tax credit from the government for the tax paid. Shareholders receive a net dividend plus a tax credit equal to the imputation rate times gross dividends. If the shareholder is a basic rate taxpayer the tax liability is fully cancelled out by the tax credit and no further tax is payable. A higher rate taxpayer needs to pay additional tax, equal to tax at the higher rate on the gross dividend less the tax credit. The net dividend income for shareholders, after all taxes, can be derived:

$$
£ 1,000\left(1-\mathrm{t}_{\mathrm{C}}\right) * \frac{(1-\mathrm{m})}{(1-\mathrm{s})}
$$

where $t_{C}$ and $m$ are as in equation (1), and $s=$ the imputation tax rate.

For basic rate tax payers, $\mathrm{m}=\mathrm{s}$, and net dividend income reduces to:

$$
£ 1,000\left(1-\mathrm{t}_{\mathrm{C}}\right)
$$

For tax exempt shareholders where $m=0$, the net dividend income is:

$$
£ 1,000 \frac{\left(1-t_{C}\right)}{(1-s)}
$$


For a firm that has $£ 1,000$ to be devoted to dividends after corporation tax of 33 percent, it follows that the basic rate tax payer has net dividend income of $£ 670$, the higher rate taxpayer $(\mathrm{m}=40$ percent $)$ has net dividend income of $£ 502.50$, and the tax exempt shareholder gets $£ 837.5$.

Net dividend incomes under the imputation and the classical systems are presented in Table 2. The impact of the decrease in corporation tax to 31 percent, 1997, is also shown. The lower the rate of corporation tax, ceteris pari$b u s$, the greater the dividend income received by the shareholders. If we compare the dividend incomes under the two tax regimes, it can be seen that the dividend incomes under the imputation system are greater than the dividends under the classical system, essentially because the distributed profits (dividends) under the classical system are subject to double taxation (corporation tax plus income tax).

With corporation tax at 33 percent the firm in the example pays a net dividend of $£ 670$. Under the imputation system the notional gross dividend is $£ 837.50$. ACT is 20 percent of $£ 837.50$, equal to $£ 167.50$. We have the following definitions:

$$
\text { Gross Dividend }=\frac{\text { Net Dividend }}{1-\mathrm{s}}(5)
$$

Net Dividend $=$

Gross Dividend x (1 - s)
We have seen that a higher rate tax-payer is liable for more tax over and above the tax credit, and the tax exempt shareholder receives a refund equal to the tax credit. The higher rate taxpayer is liable to tax at 40 percent of the gross dividend of $£ 837.50$, which is $£ 335$. With a tax credit of $£ 167.50$ the shareholder must pay a further $£ 167.50$. This represents 25 percent of the net dividend of $£ 670$, so the effective rate of tax on the net dividend received is 25 percent for the higher rate $(m=40$ percent $)$ taxpayer. The tax exempt shareholder receives a refund of $£ 167.50$ so the effective rate of tax on net dividends received is -25 percent. The general formula for the effective rate of tax on the net dividend received can be derived as follow:

Effective tax rate on net dividend $=$ (tax payable of gross dividend - tax credit)/net dividend $=$

$$
\begin{aligned}
& \frac{\frac{d}{1-s} m-\frac{d}{1-s} s}{d}=\frac{(d m-d s) \frac{d}{1-s}}{d} \\
& =\frac{m-s}{1-s}
\end{aligned}
$$

where $d=$ net dividend

Under the imputation tax system, different types of stockholders may have different tax preferences for or against dividends. If a firm retains profits as an alternative to paying a dividend, this should be capitalised in share price. If this represents a capital gain for shareholders then it is taxable (when the gain is realized). The ques- 
Gadjah Mada International Journal of Business, May-August 2006, Vol. 8, No.2

tion is whether shareholders have a tax preference for dividends or capital gains. Assuming the retained earnings are fully capitalised in share price, and is subject to capital gains tax, we can make a comparison as follows. The alternatives are to pay a net dividend or to retain this amount in the firm. If the rate of capital gains tax is $z$ and stockholders have a capital gain of $£ 1$, then the after-tax amount received is $(1-z) . £ 1$ of net dividend provides after tax income of $(1-m) /(1-s)$. In this situation, shareholders should prefer dividends only if the value of after-tax dividend is greater than the value of after-tax capital gain, that is $\{(1-\mathrm{m}) /$ $(1-\mathrm{s})\}>(1-\mathrm{z})$. On the contrary, capital gains will be preferred to dividends if: $(1-\mathrm{z})>\{(1-\mathrm{m}) /(1-\mathrm{s})\}$. (Chui et al. 1992).

Assuming that the stockholder's effective rate of capital gain tax is zero (e.g., realization of capital gain is delayed indefinitely), we can compare the value of after-tax dividend or the ratio $(1-\mathrm{m}) /(1-\mathrm{s})$ with 1 (one). If the value of this ratio is larger than one, this indicates a tax incentive to receive dividends. Conversely, if the value of this ratio is less than one, this indicates a tax incentive to receive capital gains, or in other words, a value less than one indicates a tax preference against dividends. The ratio value of one indicates indifference between dividends or capital gains.

Table 3 shows the value of the ratio $(1-m) /(1-s)$ for three types of shareholders during the period 19851999. From the three types of share-
Table 3. Tax Preference For and Against Dividends 19851999

Tax Preference For Dividend $(>1)$ and Against Dividend ( $<1)$

\begin{tabular}{|c|c|c|c|}
\hline \multicolumn{4}{|c|}{ Ratio : $(1-m) /(1-s)$} \\
\hline Year & Exempt & $\begin{array}{l}\text { Basic } \\
\text { Rate }\end{array}$ & $\begin{array}{l}\text { Top } \\
\text { Rate }\end{array}$ \\
\hline 1985 & 1.43 & 1 & 0.57 \\
\hline 1986 & 1.41 & 1 & 0.56 \\
\hline 1987 & 1.37 & 1 & 0.55 \\
\hline 1988 & 1.33 & 1 & 0.80 \\
\hline 1989 & 1.33 & 1 & 0.80 \\
\hline 1990 & 1.33 & 1 & 0.80 \\
\hline 1991 & 1.33 & 1 & 0.80 \\
\hline 1992 & 1.33 & 1 & 0.80 \\
\hline 1993 & 1.29 & 1 & 0.77 \\
\hline 1994 & 1.25 & 1 & 0.75 \\
\hline 1995 & 1.25 & 1 & 0.75 \\
\hline 1996 & 1.25 & 1 & 0.75 \\
\hline 1997 & 1 & 1 & 0.75 \\
\hline 1998 & 1 & 1 & 0.75 \\
\hline 1999 & 1 & 1 & 0.66 \\
\hline
\end{tabular}

holders, it is clear that tax-exempt shareholders such as pension funds will have a strong preference for dividends since the value of the ratios were greater than one. Basic-rate stockholders would be indifferent over the period because the marginal rate of personal income tax on dividend income is set equal to the rate of imputation $(\mathrm{m}=\mathrm{s})$. On the other hand, the top-rate shareholders have a preference against dividend payments. 
It is interesting to note that table 3 shows the decline in the incentive to receive dividend income for tax-exempt stockholders. The value of the ratio for tax-exempt shareholders decreased from 1.43 in 1985 to 1 in 1997. The decrease in the basic rate of income tax has reduced the imputation rate, and hence lowered the value of the tax credit paid out to the tax-exempt shareholders, until it disappeared altogether in 1997. From July 1997, pension funds and most of the UK corporate shareholders (including authorized unit trusts) have been no longer be entitled to the payment of the related tax credit. Thus, the incentive to receive dividend for tax-exempt shareholders has declined significantly.

Table 4 shows the effective rate of income tax on dividends received by shareholders under the imputation tax system before and after the 1997 abolition of tax credit on dividends. Before the abolition the effective rate is given by Equation (7). Following the abolition the tax-exempt institutions were treated, with respect to dividend income, in the same way as basic rate taxpayers, i.e. no tax refund and no further tax to pay, effective rate $=0$ percent. The effective rate for higher rate taxpayers remained the same. Taxes on capital gains are not assumed to be zero, but the same as income tax rates which is the prevailing system in the UK. However, the effective rates on capital gains are likely to be lower than the income tax rate because capital gains are taxed only on realization, there are benefits from deferring the payment, and various allowances and indexation rules apply (Lasfer 1995). For example, in 1999, each of a husband and wife 'living together' benefit from the annual capital gains exemption of $£ 7,100$ when shares are sold. A shareholder is also entitled to an indexation allowance, which provides protection from the effect of inflation.

As we can see the 1997 abolition of the tax credit has decreased the attractiveness of dividend income relative to capital gains for the group of

Table 4. Effective Rate of Income Tax on Net Dividend Received Before and After the 1997 Abolition of the Tax Credit on Dividend

Effective Rates of Income Tax on Net Dividend Received

\begin{tabular}{|c|c|c|c|c|}
\hline \multirow[b]{2}{*}{ Shareholders } & \multicolumn{2}{|c|}{$\begin{array}{l}\text { Before the Abolition } \\
\text { of Tax Credit }\end{array}$} & \multicolumn{2}{|c|}{$\begin{array}{l}\text { After the Abolition } \\
\text { of Tax Credit }\end{array}$} \\
\hline & $\begin{array}{c}\text { Dividend } \\
\text { Income Tax }\end{array}$ & $\begin{array}{c}\text { Capital Gain } \\
\text { Tax }\end{array}$ & $\begin{array}{l}\text { Dividend } \\
\text { Income Tax }\end{array}$ & $\begin{array}{c}\text { Capital } \\
\text { Gain Tax }\end{array}$ \\
\hline Tax-exempt & -25 percent & 0 percent & 0 percent & 0 percent \\
\hline Basic rate & 0 percent & $\leq 23$ percent & 0 percent & $\leq 23$ percent \\
\hline Top rate & 25 percent & $\leq 40$ percent & 25 percent & $\leq 40$ percent \\
\hline
\end{tabular}


Gadjah Mada InternationalJournal of Business, May-August 2006, Vol. 8, No. 2

shareholders whose dividend incomes were not taxed. These shareholders, most notably the pension funds, experienced a sharp increase in their effective tax rates on net dividends received, i.e. from -25 percent to zero. However, this significant tax change will not necessarily induce those shareholders to shift their preferences from dividends toward capital gains since the tax preference ratio $\{(1-\mathrm{m}) /(1-\mathrm{s})\}$ is equal to one. Thus, they should now be indifferent between capital gains and dividends.

\section{The Objective of the Study}

Under market imperfections, the study of corporate dividend policy has long been the subject of theoretical and empirical research. Any change in an imperfection may lead to a shift in the market equilibrium, and this provides an opportunity to test equilibrium theories. One such event is the 1997 abolition of the tax-credit on dividends for tax exempt shareholders such as pension funds. Through the abolition of tax credit paid to pension funds and companies, combined with a decrease in the corporate tax burden from 33 percent to 31 percent in 1997 , the United Kingdom government attempted to use the tax system to encourage lower dividends and higher reinvestment. The 1997 abolition of the tax credit on dividends, therefore presents a changing tax scenario in which theories of dividend can betested empirically. The objective of this research is to examine the impact of the
1997 abolition of the dividend tax credit on ex-dividend day abnormal stock returns.

\section{The Literature Review}

If a share is purchased on the day before the ex-dividend day (the last cum-dividend day), the buyer will receive the dividend on the payment day. However, if the share is purchased on the ex-dividend day, the buyer will not receive the dividend. Therefore, the ex-dividend price should be lower than the cum-dividend price to reflect the lost dividend. In prefect capital markets, the share-price drop should equal the dividend per share.

The theoretical analysis of share price behavior around the ex-dividend day compares the expected share-price drop to the dividend per share. A shareprice drop may provides arbitrage profit for buying (selling) on the cum-dividend day and selling (buying) on the ex-dividend day. Since investors are interested in after-tax returns, differential taxation of dividends and capital gains should affect the analysis.

If a shareholder were to sell her share before it goes ex-dividend, she would receive $P_{\text {cum }}$ (price before the share goes ex-dividend) minus the tax on any capital gain $\left[\mathrm{z}\left(\mathrm{P}_{\text {cum }}-\mathrm{P}_{\mathrm{o}}\right)\right]$; where $P_{o}$ is original price. If she were to sell the stock after it goes ex-dividend (price $=\mathrm{P}_{\mathrm{ex}}$ ), her wealth would be equal to dividend income after tax [d (1- m)] plus the after tax return on the sale of the share $\left[\mathrm{P}_{\mathrm{ex}}-\mathrm{z}\left(\mathrm{P}_{\mathrm{ex}}-\mathrm{P}_{\mathrm{o}}\right)\right]$. Elton and Gruber (1970) show that under the 
classical system, stockholders are indifferent between buying or selling stocks before or after the ex-dividend day if these two days' after-tax returns are equal:

$$
\begin{aligned}
& P_{\text {cum }}-Z\left(P_{\text {cum }}-P_{0}\right)= \\
& P_{e x}-Z\left(P_{e x}-P_{0}\right)+d(1-m)
\end{aligned}
$$

where:

$\mathrm{P}_{\text {cum }}=$ price of a share before it goes ex-dividend

$\mathrm{P}_{\mathrm{o}} \quad=$ original purchase price

$\mathrm{P}_{\mathrm{ex}}=$ price of a share after it goes exdividend

$\mathrm{z} \quad=$ the capital gain tax rate

$\mathrm{m}=$ the marginal tax rate on dividend income

$\mathrm{d}=$ the amount of dividend

Elton and Gruber point out that when there is a tax penalty on dividends $(m>z)$, the share price drop $\left(\mathrm{P}_{\text {cum }}-\mathrm{P}_{\text {ex }}\right)$ on the ex-day is less than the dividend amount (d). In this case, the observed ex-day returns are abnormally positive. Consider an individual investor who faces tax rates on capital gains of $z$ and on dividend incomes of $m$, where $m>z$. If we assume that transaction costs are zero, the ex-day return (before tax) of the investor for a strategy of buying cum-dividend and selling ex-dividend is:

$$
\mathrm{R}=\frac{\left(\mathrm{P}_{\text {ex }}-\mathrm{P}_{\text {cum }}\right)+\mathrm{d}}{\mathrm{P}_{\text {cum }}}
$$

and this return will be positive if the price decline $\left(\mathrm{P}_{\text {cum }}-\mathrm{P}_{\mathrm{ex}}\right)$ on ex-divi- dend day is less than the amount of the dividend (d), or after-tax returns is:

$$
\mathrm{R}=\frac{\mathrm{d}}{\mathrm{P}_{\text {cum }}}\left[1-\frac{(1-\mathrm{m})}{(1-\mathrm{z})}\right]>0
$$

This result shows that theobserved ex-day returns are positive since the tax rate on dividend incomes $(\mathrm{m})$ is greater than the tax rate on capital gains (z).

Lasfer (1995) develops a model based on study by Elton and Gruber above, and relates ex-dividend day returns to differential taxation of capital gains and dividends in the UK. Under the UK imputation system, his model is as follows:

$\mathrm{P}_{\text {cum }}-\mathrm{z}\left(\mathrm{P}_{\text {cum }}-\mathrm{P}_{0}\right)=$

$P_{e x}-z\left(P_{e x}-P_{0}\right)+d\left[\frac{1-m}{1-s}\right]$

where $d$ is the dividend net of the tax credit deducted at company level at rate $s$.

Rearranging equation (11) above, we get the ex-dividend day drop-off ratio $\left(\mathrm{DoR}_{\mathrm{ex}}\right)$ :

$\mathrm{DoR}_{\mathrm{ex}}=\frac{\mathrm{P}_{\text {cum }}-\mathrm{P}_{\mathrm{ex}}}{\mathrm{d}}=\frac{(1-\mathrm{m})}{(1-\mathrm{s})(1-\mathrm{z})}$ (12)

The indifference equation (11) can also be arranged to yield ex-dividend day return $\left(\mathrm{R}_{\mathrm{ex}}\right)$; buying a share before it goes ex-dividend and selling it after the ex-dividend day: 
Gadjah Mada InternationalJournal of Business, May-August 2006, Vol. 8, No. 2

$$
\begin{aligned}
R_{e x} & =\frac{P_{e x}+d-P_{\text {cum }}}{P_{\text {cum }}}= \\
& {\left[1-\frac{(1-m)}{(1-s)(1-z)}\right] \frac{d}{P_{\text {cum }}} }
\end{aligned}
$$

In a rational market, the fall in price on the ex-dividend day should reflect the value of dividend vis-à-vis capital gain to the stockholders. Since dividends and capital gains are taxable at different rates, the relative tax rate on these two types of income affect the decision. The terms on the right-hand side of equations (12) and (13) above reflect the tax differential between capital gains and dividends. Under the tax hypothesis, ex-dividend day returns are negatively correlated with the capital gain tax rate (z) and the tax credit (s), but positively related to dividend yield $\left(\mathrm{d} / \mathrm{P}_{\text {cum }}\right)$ and the personal income tax rate $(\mathrm{m})$. In this situation, for a taxexempt shareholder, such as a pension fund, whose marginal income tax rate and capital gain tax are equal to zero $(\mathrm{m}=\mathrm{z}=0)$, the drop-off ratio will be higher than one and the ex-dividend day returns will be negative.

Many of the ex-dividend day share price behavior studies consider tax reforms during a sample period. Lasfer (1995) examined share price behavior on ex-dividend days before and after tax reform of 1988 in the United Kingdom. The introduction of the 1988 Income and Corporation Taxes Act reduced substantially the tax differen- tial between capital gains and dividends in the UK. He finds that in the pre-1988 period, ex-dividend day returns were positive and significant while in the post-1988 period, ex-dividend day returns were negative and insignificant. He concludes that exdividend day share prices were affected by taxes but not by short-term trading.

Bell and Jenkinson (2002) analyze the ex-day share prices behavior before and after the Finance Act 1997 in the United Kingdom. The main effect of this tax reform was to abolish the right of pension fund to be repaid the tax credit on dividend paid on or after 2 July 1997. The pension funds experienced 20 percent drop in the value of their net dividend income on UK equities. They tested the hypothesis that price-drop-to-dividend ratio (DOR) declined significantly after the Finance Act 1997 since the pension funds were the marginal investors in the UK equities and dividend taxes affected equities values. To test this hypothesis, they compared estimated drop-off ratios before and after the Finance Act 1997 using the following regression model:

$$
\begin{aligned}
{\left[\frac{\mathrm{P}_{\mathrm{c}}-\mathrm{P}_{\mathrm{ex}}}{\mathrm{P}_{\mathrm{c}}}\right]_{\mathrm{i}} } & \alpha+\beta\left[\frac{\mathrm{D}}{\mathrm{P}_{\mathrm{c}}}\right]_{\mathrm{i}}+ \\
& \beta_{\mathrm{FA}}\left[\operatorname{PostFA97} \frac{\mathrm{D}}{\mathrm{P}_{\mathrm{c}}}\right]_{\mathrm{i}}+\varepsilon_{\mathrm{i}}
\end{aligned}
$$


where:

$\mathrm{P}_{\mathrm{c}}=$ the cum-dividend price of a share (before it goes ex-dividend)

$\mathrm{P}_{\mathrm{ex}}=$ price of a share after it goes exdividend

$\mathrm{D}=$ the dividend per share

$\varepsilon=$ error terms

The drop-off ratios are estimated as the slope coefficient in the regression model. The tax-induced change is incorporated in this model by using an interactive zero-one dummy (Post Finance Act 1997) for whether or not the observation declines during the Post FA 97 periods. The null hypothesis of $\beta_{F A}=0$ is tested against the alternative hypothesis of $\beta_{F A}<0$. If the null hypothesis is rejected, this result indicates that the drop-off ratios changed following the Finance Act 1997. Bell and Jenkinson find significant changes in price-drop-to-dividend ratio (DOR), especially for high dividend yield firms. Before the Finance Act 1997 (FA97), there was a strong preference of pension funds for dividend income. The reductions in average DORs of 13 percent to 28 percent provides strong evidence that pension funds were the effective marginal investors for highyielding firms, and that taxation influences the valuation of firms.

\section{The Hypothesis}

The 1997 abolition of the tax credit has important implications for the analysis of ex-dividend day returns. The substantial increase in the effec- tive rate of tax on dividends received by tax-exempt institutional investors, from -25 percent to zero, provides an ideal opportunity to examine ex-dividend day stock returns behavior.

The ex-dividend day return $\left(\mathrm{R}_{\mathrm{ex}}\right)$ from a strategy of buying a share before it goes ex-dividend and selling it after the ex-dividend day is composed of a dividends component and a capital gain (loss) component. The equation is:

$\mathrm{R}_{\mathrm{ex}}=\frac{\mathrm{d}+\mathrm{P}_{\mathrm{ex}}-\mathrm{P}_{\mathrm{cum}}}{\mathrm{P}_{\mathrm{cum}}}$

Alternatively, the rate of return on the ex-dividend day can be written as follows:

$$
\mathrm{R}_{\text {ex }}=(1-\mathrm{DOR}) \frac{\mathrm{d}}{\mathrm{P}_{\text {cum }}}
$$

DOR is defined as the 'drop-off ratio,' the ratio of the fall in price to the dividend paid.

Hence:

$$
\mathrm{DOR}=\frac{\mathrm{P}_{\text {cum }}-\mathrm{P}_{\mathrm{ex}}}{\mathrm{d}}
$$

Elton and Gruber (1970) show that under the classical system, the price-drop-to-dividend ratio (DOR) is expected to equal the relative tax differential between dividend and capital gain, where $m$ and $z$ are the marginal tax rate on dividend income and the capital gain tax rate, respectively: 
Gadjah Mada International Journal of Business, May-August 2006, Vol. 8, No. 2

$$
\mathrm{DOR}=\frac{\mathrm{P}_{\text {cum }}-\mathrm{P}_{\mathrm{ex}}}{\mathrm{d}}=\frac{1-\mathrm{m}}{1-\mathrm{z}}
$$

Lasfer (1995) develops a model based on study by Elton and Gruber above and under the UK imputation system, the price-drop-to-dividend ratio is as follows:

$$
\begin{aligned}
\text { DOR } & =\frac{P_{\text {cum }}-P_{e x}}{d} \\
& =\frac{1-m}{(1-s)(1-z)}
\end{aligned}
$$

where $s$ is the rate of imputation credit.

As discussed earlier, the main impact of the 1997 dividend tax change was to remove the ability of tax-exempt investors such as pension funds to reclaim tax credit, thereby decreasing their dividend income by 20 percent. Before the 1997 abolition of tax credit $(s=0.20)$, if ex-dividend day share price behavior were solely influenced by the tax preference of taxexempt shareholders (marginal income tax rate and capital gain tax are equal to zero or $\mathrm{m}=\mathrm{z}=0$ ), the drop-off ratio would be equal to 1.25 . Following the 1997 abolition of tax credit ( $\mathrm{s}=0$ ), the drop-off ratio would be expected to fall by 20 percent. Therefore, if pricedrop-to-dividend ratios after the abolition were lower than before the abolition, then the ex-dividend day returns should have increased following the 1997 abolition of the tax credit.
By comparing abnormal returns on the ex-dividend days in the pre- and post-abolition periods, we can investigate the effect of the 1997 tax change on the ex-dividend day abnormal returns. The hypothesis to be tested is as follows:

The 1997 abolition of the tax credit on dividends had no effect on exdividend day abnormal returns.

\section{Data and Methodology}

\section{Data}

Data on ex-dividend dates, dividend per share, share prices, dividend yield, market value of equity and market index were collected to test the impact of the 1997 abolition of taxcredits on the ex-dividend day abnormal returns. These data was obtained from the London Stock Exchange (Datastream International and Extel UK Annual Financial News Summary) over the sample period of this study (1/ $1 / 1995$ to $31 / 12 / 1999)$. All cash dividend distributions were collected in the form of interim and final dividends.

The main selection criterion is that there should be at least 5 days between the ex-dividend day and other announcement days such as earnings, stock splits and right issues. The reason for this is that the ex-dividend abnormal returns should not be contaminated by other announcement effects, a concern first raised by Miller and Scholes (1982). Furthermore, the 
sample observations were chosen from actively traded shares to reduce the thin trading problems. Infrequently traded shares have the potential for resulting in biased estimates of abnormal returns, and consequently unspecified tests statistics in the event study (Strong 1992). A sample of $1,042 \mathrm{ob-}$ servations was selected in this study.

It is recognized that this data set has encountered some limitations. Since ownership data is very difficult to obtain, the sample firms may not represent institution portfolio holdings, which provide important link to connect the empirical results to institutional investors such as pension funds.

Furthermore, even though the number of observations $(1,042)$ was large, this came from 105 FT All Share companies, thus the size of sample firms was not huge. One problem when dealing with stock prices is volatility within the sample firms, and normally this is exacerbated when the data sample is not large. To investigate the ex-dividend share price behavior in relation to the actual dividend, this sample was extended to 169 companies with 1,440 observations. This study realizes that share prices are very volatile and the variance of the average price drop is therefore large. The mean is significantly affected by several outliers in the sample. In order to measure the average price drop correctly, this study deleted these extreme value from the observations. Due to the extreme values, sixty (60) ex-dividend day events were deleted. More- over, since this study examines the behavior of share prices on ex-dividend day, zero-price-change observations were excluded from the sample, and a further 34 ex-dividend day events were eliminated. Eventually the final sample of 1,346 ex-dividend day observations were used in the analysis of price-drop to dividend ratios.

\section{Methodology}

In order to examine the effect of the 1997 abolition of tax credits on the behavior of share prices on the exdividend days, this study analyses abnormal returns on ex-dividend days over the period from 1 January 1995 to 31 December 1999. The market model is used to measure abnormal returns. To obtain coefficients of the market model, security returns are regressed against FT All Shares Index (-200: -41) using trading days relative to exdividend days. The rationale for using a large number of observations (160 days) is to minimize the impact of company specific events such as earnings or right issue announcement on the parameter estimates.

The market model equation is as follows:

$$
\mathrm{R}_{\mathrm{jt}}=\alpha_{\mathrm{j}}+\beta_{\mathrm{j}} \mathrm{R}_{\mathrm{mt}}+\varepsilon_{\mathrm{t}}
$$

where:

$\mathrm{R}_{\mathrm{jt}}=$ the daily security return for company $j$ on day $t$

$\alpha_{j}=$ the intercept for company

$\beta_{\mathrm{j}}=$ beta for company $j$ 
Gadjah Mada International Journal of Business, May-August 2006, Vol. 8, No. 2

$\mathrm{R}_{\mathrm{mt}}=$ the daily return of FT All Shares Index on day $t$, and

$\varepsilon_{\mathrm{t}}=$ the stochastic disturbance term

Once the parameters of the market model equation have been estimated, we use them to calculate predicted returns $(\mathrm{R})$ for each company on ex-dividend day. Abnormal returns (AR) are calculated as indicated below:

$$
\mathrm{AR}_{\mathrm{jt}}=\mathrm{R}_{\mathrm{jt}}-\stackrel{\mathrm{R}}{\mathrm{jt}}_{\mathrm{j}}
$$

where:

$\mathrm{AR}_{\mathrm{jt}}=$ abnormal return for company $j$ on day $t$

$\mathrm{R}_{\mathrm{jt}}=$ the daily security return for company $j$ on day $t$

$\stackrel{\mathrm{R}}{\mathrm{jt}} \quad=$ the estimated/predicted return for company $j$ on day $t$

To test for the significance of the mean ex-dividend day abnormal returns $\left(\mathrm{AR}_{\mathrm{j}, \mathrm{ex}}\right)$, the standard deviation of the residuals (market model) is used to compute the standardized abnormal return (SAR). The standardized abnormal returns are calculated using Patell's (1976) method. The SAR is computed for ex-dividend day as follows:

$$
\operatorname{SAR}_{j t}=\frac{\mathrm{AR}_{\mathrm{jt}}}{\sigma_{\mathrm{j}} \sqrt{\left[1+\frac{1}{\mathrm{~T}_{j}}+\frac{\hat{\mathrm{h}}}{\hat{\mathrm{H}}}\right]}}
$$

where:

$\mathrm{AR}_{\mathrm{jt}}=$ the abnormal return on day $t$ for company $j$
$\mathrm{h}_{\mathrm{t}}=\left(\mathrm{R}_{\mathrm{mt}}-\overline{\mathrm{R}}_{\mathrm{m}}\right)^{2}$

$\hat{\mathrm{H}}=\sum_{\tau=1}^{\mathrm{T}_{\mathrm{i}}}(\hat{\mathrm{h}})$

$\mathrm{R}_{\mathrm{mt}}=$ the market return on day $t$

$\overline{\mathrm{R}}_{\mathrm{m}}=$ the average market return over the estimation period

$\mathrm{T}_{\mathrm{j}} \quad=$ the number of days in the estimation period)

$\sigma_{j}=$ the standard deviation of the residuals (market model) during the estimation period

These standardized abnormal returns are aggregated to construct $Z$ statistic as follows:

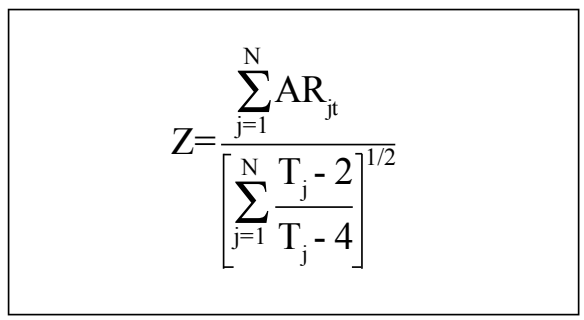

To examine the significance of the mean ex-day abnormal returns, the following hypotheses are tested:

$\mathrm{H}_{\mathrm{o}}$ : The ex-day Abnormal Return is equal to zero $\left(\mathrm{AR}_{\mathrm{ex}}=0\right)$

$\mathrm{H}_{\mathrm{a}}$ : The ex-day Abnormal Return is not equal to zero $\left(\mathrm{AR}_{\mathrm{ex}} \neq 0\right.$ )

Since the null hypothesis of $A R_{\mathrm{ex}}$ $=0$ is tested against the alternative of $A R_{\text {ex }} \neq 0$, the two-tailed statistical test is used. For the conventional significant level of 5 percent, the computed $Z$-statistic is compared with $Z_{0.025}$ which is 1.96 . The null hypothesis will be rejected if the $\mid Z$-statistid is greater than 1.96 . 
Finally, this study will conduct a test on whether the 1997 abolition of tax credit on dividend has changed the ex-dividend day returns behavior. To examine whether the 1997 abolition of the tax credit on dividends had no effect on ex-dividend day abnormal returns, the two-tailed statistical test is appropriate. To test for differences in ex-day abnormal returns between two samples, the standardized abnormal returns $\left(\mathrm{SAR}_{\mathrm{jex}}\right)$ are split into pre-abolition (1/1/1995 to $1 / 7 / 1997)$ and postabolition periods (2/7/1997 to $31 / 12 /$ 1999) and following statistical hypotheses are tested: $\mathrm{H}_{\mathrm{o}}: \mu_{1}=\mu_{2}$ versus $\mathrm{H}_{\mathrm{a}}$ : $\mu_{1} \neq \mu_{2}$ (where: $\mu_{1}=$ the sample means of $\mathrm{SAR}_{1, \mathrm{ex}}$ for the pre-1997 abolition period; and $\mu_{2}=$ the sample means of SAR $_{2, \text { ex }}$ for the post-1997 abolition period).

The conventional significant level of 5 percent is used to test this hypothesis. The null hypothesis $\left(\mathrm{H}_{\mathrm{o}}\right)$ is rejected if $|Z|>Z_{\alpha}$ and there is a significant difference between the preand post-abolition mean ex-dividend day returns. This would imply that the ex-dividend day returns changed following the 1997 abolition of tax credit on dividend or in other words, exdividend day abnormal returns were affected by the abolition of tax credit on dividends.

\section{Empirical Tests and Results}

This empirical study tests of the significance of the mean ex-day abnormal returns over the pre-and postabolition periods. The pre-abolition period includes the 2.5 years before the abolition of tax credits on dividend $(1 / 1 / 1995$ to $1 / 7 / 1997)$ and the postabolition includes the 2.5 years after the abolition (2/7/1997 to 31/12/1999).

Ex-day abnormal returns $\left(\mathrm{AR}_{\mathrm{j}, \mathrm{ex}}\right)$ and standard deviation of the residuals (market model) are used to compute the standardized abnormal returns (SAR). These standardized abnormal returns are aggregated as in Patell (1976) to construct $Z$-scores. To examine the significance of the mean exday abnormal returns, a two-tailed statistical test is used since the null hypothesis of $\mathrm{AR}_{\mathrm{ex}}=0$ is tested against the alternative of $\mathrm{AR}_{\mathrm{ex}} \neq 0$. For the conventional significance level of 5 percent, the computed $Z$-statistic is compared with $Z_{0.025}$ which is 1.96 . The null hypothesis is rejected if the |Z-statistic| is greater than 1.96.

The difference in ex-day abnormal returns between pre- and postabolition periods is also examined. The two-sample mean test is employed on the standardized abnormal returns to test whether the abnormal returns on ex-dividend day $\left(\mathrm{AR}_{\mathrm{ex}}\right)$ were affected by the 1997 abolition of tax credits on dividend. Since the null hypothesis of $\mathrm{AR}_{\mathrm{ex}}$ pre-abolition $=\mathrm{AR}_{\mathrm{ex}}$ post-abolition is tested against the alternative of $A R_{\text {ex }}$ post-abolition $\neq A R_{\text {ex }}$ pre-abolition, the two-tailed statistical test is appropriate The conventional significance level of 5 percent is used to test this hypothesis. The null hypothesis $\left(\mathrm{H}_{\mathrm{o}}\right)$ is rejected if $|Z|>Z_{\alpha}$ and there is significant difference between 
the pre-and post-abolition mean exdividend day returns.

Table 5 presents the results of significance tests for mean ex-day abnormal returns. Abnormal returns on ex-dividend days $\left(\mathrm{AR}_{j, e x}\right)$ and their $Z$ scores are provided for the pre- and post-abolition of tax-credit periods. To better explain the distribution of $A R_{j, e x}$, the percentage of positive values and the median values are provided in this table. Test results by dividend yield quintiles are also provided for the pre-and post-abolition.
The mean ex-day abnormal returns (hereafter, AR) for all quintiles over the pre-abolition periods (1/1/ 1995 to $1 / 7 / 1997$ ) is 0.0580 percent and over the post-abolition periods ( $2 /$ $7 / 1997$ to $31 / 12 / 1999$ ) is -0.1459 percent. This decline in abnormal returns is confirmed by the median $A R$ of 0.0299 percent over the pre-abolition periods, declining to -0.0915 percent during the post-abolition periods, and by the percentage of positive $A R$ declining from 50.65 percent to 46.52 percent. The $Z$-score of the mean $A R$

Table 5.Ex-dividend Day Abnormal Returns -All Quintiles and Per Quintile

\begin{tabular}{|c|c|c|c|c|c|c|}
\hline \multicolumn{7}{|c|}{ Pre-Abolition Period (1/1/1995-1/7/1997) } \\
\hline & DY & $\mathbf{N}$ & AR & Z-Score & Median & $\begin{array}{c}\text { Percent } \\
\text { Positive }\end{array}$ \\
\hline All quintiles & 3.9699 & 541 & 0.0580 & 1.6850 & 0.0299 & 50.65 percent \\
\hline Quintile 1 & 2.2330 & 107 & 0.0299 & 0.4689 & -0.0230 & 46.73 percent \\
\hline Quintile 2 & 3.1488 & 107 & -0.0252 & 0.4502 & 0.0439 & 51.40 percent \\
\hline Quintile 3 & 3.8489 & 116 & 0.0418 & 0.7672 & -0.0126 & 50.00 percent \\
\hline Quintile 4 & 4.5592 & 104 & 0.1452 & 1.2639 & 0.1717 & 53.85 percent \\
\hline Quintile 5 & 6.0598 & 107 & 0.1091 & 0.8605 & 0.0765 & 53.27 percent \\
\hline \multicolumn{7}{|c|}{ Post-Abolition Period (2/7/1997-31/12/1999) } \\
\hline & DY & $\mathbf{N}$ & $\mathbf{A R}$ & Z-Score & Median & $\begin{array}{l}\text { Percent } \\
\text { Positive }\end{array}$ \\
\hline All quintiles & 3.8546 & 501 & -0.1459 & -1.5599 & -0.0915 & 46.52 percent \\
\hline Quintile 1 & 1.8439 & 96 & 0.0032 & -0.1867 & -0.0659 & 47.92 percent \\
\hline Quintile 2 & 2.9254 & 112 & 0.0726 & 0.4160 & -0.0203 & 50.00 percent \\
\hline Quintile 3 & 3.6341 & 99 & -0.1272 & -0.3532 & -0.1278 & 43.43 percent \\
\hline Quintile 4 & 4.4492 & 100 & -0.0270 & -0.5711 & -0.1453 & 47.00 percent \\
\hline Quintile 5 & 6.4203 & 94 & -0.7174 & $-2.9678 *$ & -0.1592 & 42.55 percent \\
\hline
\end{tabular}

Notes: $\mathrm{N}$ is the number of observations

$\mathrm{AR}$ is the mean ex-day abnormal returns in percentage

$\mathrm{Z}$ is the statistical score for significance of the mean abnormal returns.

* The significance level of 5 percent for $Z$ is 1.96

DY is the average dividend yield percentage 
for all quintiles over the pre-abolition periods is an insignificant 1.6850 and that for the post-abolition periods $A R$ is insignificant at -1.5599 . These results appear to indicate that the 1997 abolition of tax credits resulted in lower ex-day abnormal returns in the postabolition periods. To investigate whether the ex-day abnormal returns changed following the 1997 abolition of tax credits, this study conducts comparison tests.

The results of comparison test between two sample periods are presented in Table 6 . The comparison of ex-day abnormal returns between preand post-abolition periods shows that ex-day returns declined significantly following the 1997 abolition of tax credits $(\mathrm{t}$-value $=2.0431)$. Thus the hypothesis that ex-dividend day abnormal returns did not change following the 1997 abolition of tax credit can be rejected at the 5 percent significance level. In other words, the exdividend day returns were affected by the 1997 tax reform. Through the abo- lition of tax credit paid to pension funds and companies in 1997, the United Kingdom government attempted to use the tax system to encourage lower dividends and the exday returns declined following the new regulation.

To provide further evidence on the ex-day abnormal returns, Table 7 reports test results for individual years from 1995 to 1999 . These results show that the $Z$-scores for 1995, 1996, 1997 and 1998 are insignificant. The 1999 $A R,-0.3179$ percent, is the only significant result with $Z$-score -2.2877 . The two-sample tests presented in Table 6 also indicate that the $1999 A R$ is significantly less than the 1995 , the 1996 and 1997 AR. This evidence shows that the ex-day abnormal returns declined following the abolition of tax credits on dividend.

The decline in the ex-day abnormal returns (AR) for the post-abolition periods seems to be driven primarily by the highest dividend yield quintile. Table 5 shows that the mean $A R$ for

Table 6.Comparison of Ex-Day Abnormal Returnsin Two Samples

\begin{tabular}{|c|c|c|c|c|c|}
\hline & Post-Abolition & 1996 & 1997 & 1998 & 1999 \\
\hline Pre-Abolition & $2.0431 *$ & & & & \\
\hline 1995 & & 0.4644 & -0.1886 & 0.8096 & $2.4348 *$ \\
\hline 1996 & & & -0.6219 & 0.4571 & $1.9697 *$ \\
\hline 1997 & & & & 0.9244 & $2.4525 *$ \\
\hline 1998 & & & & & 1.0157 \\
\hline
\end{tabular}

Notes: Mean AR of different time periods are compared using the two-sample test

* Italic number is significant at the 5 percent level

Pre-Abolition: 1/1/1995- 1/7/1997

Post-Abolition: 2/7/1997-31/12/1999 
Gadjah Mada International Journal of Business, May-August 2006, Vol. 8, No. 2

Table 7. Ex-dividend Day Abnormal Returns Per Year

\begin{tabular}{|c|c|c|c|c|c|c|}
\hline Data & DY & $\mathbf{N}$ & $\mathbf{A R}$ & Z-Score & $\begin{array}{l}\text { Median } \\
\text { Positive }\end{array}$ & Percent \\
\hline 1995 & 4.0102 & 215 & 0.0303 & 1.0481 & 0.0630 & 50.70 percent \\
\hline 1996 & 3.9572 & 217 & 0.0192 & 0.4537 & -0.0134 & 49.31 percent \\
\hline 1997 (str. 1) & 3.9150 & 109 & 0.1969 & 1.6771 & 0.1067 & 54.13 percent \\
\hline 1997 (str. 2) & 3.8041 & 106 & 0.0165 & 0.3022 & 0.0551 & 51.89 percent \\
\hline 1998 & 3.8202 & 183 & -0.0471 & -0.3864 & -0.0947 & 45.36 percent \\
\hline 1999 & 3.9142 & 212 & -0.3179 & $-2.2877^{*}$ & -0.1853 & 43.40 percent \\
\hline $\begin{array}{l}\text { Total } \\
\text { Observation }\end{array}$ & & 1042 & & & & \\
\hline
\end{tabular}

Notes:

str= semester

$\mathrm{N}$ is the number of observations

$\mathrm{AR}$ is the mean ex-day abnormal returns in percentage

$\mathrm{Z}$ is the statistical score for significance of the mean abnormal returns

DY is the average dividend yield percentage*

* Italic number is significant at the 5 percent level

Pre-Abolition: 1/1/1995-1/7/1997

Post-Abolition: 2/7/1997-31/12/1999

quintile 5, 0.1091 percent, is insignificantly positive $(Z$-score $=0.8605)$ during pre-abolition periods and it drops to -0.7174 percent (significantly negative with $\mathrm{Z}$-score $=-2.9678$ ) over the post-abolition periods. This result appears to suggest that the highest dividend yield securities are likely to be held by tax-exempt investors such as pension funds that were affected by the 1997 abolition of the tax credits on dividend. This decline can be expected to describe the decline for the aggregate results of post-abolition periods.
Further investigation of the exdividend share price behavior in relation to the actual dividend paid may provide additional evidence to the earlier findings reported above. This is best done using Elton and Gruber's (1970) drop off ratios techniques. The analysis of share price movement around the ex-dividend day compares the share-price drop to the dividend per share. As described earlier, the rate of return on the ex-dividend day is composed of a dividends component and a capital gain (loss) component. The equation is: 


$$
\begin{aligned}
& \mathrm{R}_{\mathrm{ex}}=\frac{\mathrm{d}+\mathrm{P}_{\mathrm{ex}}-\mathrm{P}_{\mathrm{cum}}}{\mathrm{P}_{\mathrm{cum}}} \text { or alternatively } \\
& \mathrm{R}_{\mathrm{ex}}=(1-\mathrm{DOR}) \frac{\mathrm{d}}{\mathrm{P}_{\mathrm{cum}}}
\end{aligned}
$$

The ex-dividend day drop-off ratios

$$
\mathrm{DOR}_{\mathrm{ex}}=\frac{\mathrm{P}_{\mathrm{cum}}-\mathrm{P}_{\mathrm{ex}}}{\mathrm{D}}
$$

were computed before and after the 1997 abolition of tax credit on dividend. If price-drop-to-dividend ratios after the abolition were greater than before the abolition, then the ex-dividend day returns should have declined following the 1997 abolition of the tax credit.

This study is aware that share prices are very volatile and the variance of the average price drop is therefore large. The mean is significantly affected by several outliers in the sample. In order to measure the average price drop correctly, this study deleted these extreme value from the observations. As mentioned earlier, the initial sample was 1,042 observations from 105 companies. This was extended to 169 companies with 1,440 observations. Due to the extreme values, sixty (60) ex-dividend day events

\begin{tabular}{|c|c|c|c|c|}
\hline \multicolumn{5}{|c|}{ Pre-Abolition Period (1/1/1995-1/7/1997) } \\
\hline & DY & $\mathbf{N}$ & DOR (Mean) & Variance \\
\hline All quintiles & 3.753 & 733 & 0.519 & 0.108 \\
\hline Quintile 1 & 1.706 & 125 & 0.665 & 0.203 \\
\hline Quintile 2 & 2.904 & 154 & 0.516 & 0.132 \\
\hline Quintile 3 & 3.682 & 157 & 0.467 & 0.063 \\
\hline Quintile 4 & 4.471 & 151 & 0.483 & 0.082 \\
\hline Quintile 5 & 6.069 & 146 & 0.491 & 0.055 \\
\hline \multicolumn{5}{|c|}{ Post-Abolition Period (2/7/1997-31/12/1999) } \\
\hline & DY & $\mathbf{N}$ & DOR (Mean) & Variance \\
\hline All quintiles & $\overline{3.708}$ & $\overline{613}$ & 0.574 & 0.305 \\
\hline Quintile 1 & 1.375 & 84 & 0.761 & 0.255 \\
\hline Quintile 2 & 2.602 & 133 & 0.567 & 0.688 \\
\hline Quintile 3 & 3.471 & 119 & 0.533 & 0.230 \\
\hline Quintile 4 & 4.449 & 142 & 0.505 & 0.145 \\
\hline Quintile 5 & 6.731 & 135 & 0.575 & 0.172 \\
\hline
\end{tabular}
were deleted. Moreover, since this

Table 8. Price-Drop to Dividend Ratios (Drop Off Ratios)

Notes: $\mathrm{N}$ is number of observations (total observation $=1,346$ )

DOR is the average ex-dividend drop-off ratio

DY is the average dividend yield 
study examines the behavior of share prices on ex-dividend day, zero-pricechange observations were excluded from the sample, and a further 34 exdividend day events were eliminated. Eventually the final sample of 1,346 ex-dividend day observations were used in this analysis.

Table 8 presents the average exdividend day drop-off ratios for the pre-and post-abolition periods. The results by dividend yield quintiles are also provided for the pre-and postabolition.

The mean ex-dividend day dropoff ratios (DOR) for all quintiles over the pre-abolition periods is 0.519 and over the post-abolition periods is 0.574 . The comparison of price-drop to dividend ratios between pre-and post-abolition periods shows that drop-off ratios increased following the 1997 abolition of tax credits. The mean drop-off ratios for dividend yield group 1,2,3,4 and 5 increased, respectively, from $0.665,0.516,0.467,0.483$, and 0.491 in the pre-abolition period to 0.761 , $0.567,0.533,0.505$ and 0.575 in the post-abolition period. These results appear to indicate that the 1997 abolition of tax credits resulted in greater drop off ratios in the post-abolition periods.

To investigate whether the ex-day drop off ratios changed following the 1997 abolition of tax credits, this study conducts comparison tests. The results of comparison test between two sample periods are presented in Table 9.

The comparison tests of ex-day drop-off ratios between pre-and postabolition periods shows that drop-off ratios for all dividend yield groups increased significantly after the 1997 abolition of tax credits (t-value $=2.183$ ). The increase in the ex-day DOR for the post-abolition periods seems to be driven primarily by the highest dividend yield quintile. Table 9 shows that the mean DOR for quintile 5 is 0.491 during pre-abolition periods and it increases significantly to 0.575 over the

Table 9.Comparison Tests of DOR between Two Sample Periods

\begin{tabular}{|c|c|c|c|c|}
\hline DY & $\begin{array}{c}\text { DOR } \\
\text { Pre-Abolition }\end{array}$ & $\begin{array}{c}\text { DOR } \\
\text { Post-Abolition }\end{array}$ & Difference & T-Stat \\
\hline All quintiles & 0.519 & 0.574 & 0.055 & $2.183 *$ \\
\hline Quintile 1 & 0.665 & 0.761 & 0.096 & 1.406 \\
\hline Quintile 2 & 0.516 & 0.567 & 0.052 & 0.666 \\
\hline Quintile 3 & 0.467 & 0.533 & 0.066 & 1.368 \\
\hline Quintile 4 & 0.483 & 0.505 & 0.022 & 0.547 \\
\hline Quintile 5 & 0.491 & 0.575 & 0.084 & $2.074 *$ \\
\hline
\end{tabular}

Notes: Mean DOR of different time periods are compared using the two-sample test * Italic number is significant at the 5 percent level

Pre-Abolition: 1/1/1995- 1/7/1997

Post-Abolition: 2/7/1997-31/12/1999 
post-abolition periods with t-value of 2.074 .

This evidence is consistent with the previous findings that the 1997 abolition of tax credit on dividend resulted in lower ex-dividend day returns in the post-abolition periods than they were in the pre-abolition periods. Thus, the decrease on ex-day abnormal returns was further supported by a significant increase in the average price-drop to dividend ratios.

\section{Summary and Conclusions}

This study investigates the effect of the 1997 abolition of tax credit on the ex-day abnormal returns because the new tax regulation has an important implication for the analysis of exdividend returns. Since investors such as pension funds and other tax-exempt institutions are no longer entitled to the payment of tax credits, the effective rate of income tax increased significantly. Consequently, the amount of dividend received by tax-exempt investors declined considerably, ceteris paribus, then the ex-day abnormal returns were expected to decline.

To test whether the ex-day abnormal returns changed following the 1997 abolition of tax credits, this study uses 1042 LSE ex-day observations over the pre-abolition periods $(1 / 1 / 1995$ $1 / 7 / 1997)$ and the post-abolition periods (2/7/1997-31/12/1999). The exday $A R$ declined from 0.0580 percent during the pre-abolition periods to 0.1459 percent during the post-abolition periods. This decline in abnormal returns is confirmed by the median $A R$ of 0.0299 percent over the pre-abolition periods, declining to -0.0915 percent during the post-abolition periods, and by the percentage of positive $A R$ declining from 50.65 percent to 46.52 percent. The result of comparison test between pre-and post abolition periods shows that the ex-day abnormal returns declined significantly with a tvalue of 2.0431. From these results, it would appear that the ex-dividend day abnormal returns changed following the 1997 abolition of tax credits on dividend. This decrease in the ex-day abnormal returns was further supported by a significant increase in the average price-drop to dividend ratios. The average ex-day drop-off ratios (DOR) for all dividend yield groups increased significantly from 0.519 in the preabolition period to 0.574 in the postabolition period with t-value of 2.183 .

The decline in the ex-day $A R$ for the post-abolition periods seems to be driven primarily by quintile 5 (the highest dividend yield quintile). Quintile 5 exhibits strong dividend preference and this preference is likely caused by the imputation system that provides a tax advantage to the pension funds and other tax exempt shareholders. Statistical results show that the mean $A R$ for quintile 5, 0.1091 percent, is insignificantly positive $(Z$-score $=0.8605)$ during pre-abolition periods and it drops to -0.7174 percent (significantly negative with $Z$-score $=-2.9678$ ) over the post-abolition periods. This result appears to suggest that the highest dividend yield securities are likely to be 
Gadjah Mada International Journal of Business, May-August 2006, Vol. 8, No. 2

held by tax-exempt investors such as pension funds that were affected by the 1997 abolition of the tax credits on dividend.

This study recognizes that it encounteres some limitations. Firstly, since ownership data is very difficult to obtain, the sample firms may not represent institution portfolio holdings, which provide important link to connect the empirical results to institu- tional investors such as pension funds. Secondly, even though the number of observations was large, this came from 105 companies, thus the size of sample firms was not huge. One problem when dealing with stock prices is volatility within the sample firms, and normally this is exacerbated when the data sample is not large. Thus, these factors may reduce the strength of the findings of this empirical study.

\section{References}

Allen, F., A. Bernardo, and I. Welch. 2000. A theory of dividend based on tax clientele. Journal of Finance 55 (6): 2499-2536.

Ashton, D.J. 1991. Corporate financial policy: American analytics and UK taxation. Journal of Business Finance and Accounting 18 (4): 465-482.

Asquith, P., and D. W. Mullins. 1983. The impact of initiating dividend payments on shareholders' wealth. Journal of Business 56 (1): 77-96.

Bank of England. 1987. Companies' long-term financial decision, dividends and debt. Bank of England Quarterly Bulletin (May): 261.

Beales, G. 1998. 1998-1999 Income Tax and NIC for the Self-employed Handbook. Surrey: Croner Publication Ltd.

Bell, L., and T. Jenkinson. 2002. New evidence of the impact of dividend taxation and on the identity of the marginal investor. Journal of Finance LVII (3): 1321-1346.

Benartzi, S., R. Michaely, and R Thaler. 1997. Do changes in dividends signal the future or the Past? Journal of Finance 52: 1007-1034.

Bond, S., L.Chennels, and M.Devereux. 1995. Company dividends and taxes in the UK. Fiscal Studies 16 (3).

Brenan, M. J. 1970. Taxes, market valuation and corporate financial policy. National Tax Journal 23:417.

Brigham, E. J., and L. C. Gapenski. 1987. Intermediate Financial Management (2 ${ }^{\text {nd }}$ ed.). The Dryden Press.

Brown, G. 1997. Budget Statement. HANSARD-Parliamentary Debate, House of Commons Official Report 297 (33): 306.

Butterworths .1997. Simon's Direct Tax Service: Budget Bulletin 1997. Scotland: Thomson Litho Ltd. 
Basuki-The Impact of the Abolition of Tax Credit on ...

Central Statistical Office. 1994. Annual Supplement 1994 Edition (Economic Trends): 100.

Chui, A, N. Strong, and J. Cadle. 1992. The empirical significance of tax effects on the valuation of dividends: The UK evidence. Journal of Business Finance and Accounting 19 (4): 515-532.

DeAngelo H., L. De Angelo, and D. J. Skinner. 1996. Reversal of fortune dividend signalling and the disappearance of sustained earning growth. Journal of Financial Economics 40: 341-371.

Dyl , E. A., and J. R. Hoffmeister. 1986. A note on dividend policy and beta. Journal of Business Finance and Accounting 13 (1): 107-115.

Eades, K, P. Hess, and E. H. Kim. 1984. On interpreting security returns during the exdividend period. Journal of Financial Economics, p.20.

Easterbrook, F. H. 1984. Two agency-cost explanations of dividends. The American Economic Review LXXIV (4): 650.

Elton, E. J., and M. J. Gruber. 1970. Marginal stockholder tax rates and the clientele effect. The Review of Economics and Statistics LII (1): 68-74.

Fama, E. F., and H. Babiak. 1968. Dividend policy: An empirical analysis. The Journal of the American Statistical Association 63: 1132-1161.

Farrar, D., and L. Selwyn. 1967. Taxes, corporate financial policy and return to investors. National Tax Journal: 444-454.

Feldstein, M. S. 1970. Corporate taxation and dividend behaviour. Review of Economic Studies 37: 57-72.

Foreman, A. 1998. Tax Handbook 1998-1999. London: Allied Dunbar Assurance plc.

Grullon, G., R. Michaely, and B. Swaminathan. 2002. Aredividend changes a sign of firm maturity? Journal of Business 75 (3): 387-424.

Hakansson, N. H. 1982. To pay or not to pay dividend. Journal of Finance XXXVII (2): 415.

Jensen, M. C. 1986. Agency cost of free cash flow, corporate finance and takeovers. The American Economic Review 76 (2): 323-329.

Karpoff, J. M., and R. A. Walkling. 1988. Short-term trading around ex-dividend daysadditional evidence. Journal of Financial Economics (21): 291-298.

Kay, J. A., and M. A. King. 1990. The British Tax System ( $5^{\text {th }}$ ed.). Oxford: Oxford University Press.

Lakonishok, J., and T. Vermaelen. 1983. Tax reform and ex-dividend day behaviour. Journal of Finance XXXVIII (4): 1157.

Lakonishok, J., and T. Vermaelen. 1986. Tax-induced trading around ex-dividend days. Journal of Financial Economics (16): 287-319.

Lasfer, M.A. 1995. Ex-Day Behaviour: Tax or Short-Term Trading Effects. Journal of Finance L (3): 875-897.

Lasfer, M.A. 1996. Taxes and dividends: The UK evidence. Journal of Banking and Finance 20: 455. 
Gadjah Mada International Journal of Business, May-August 2006, Vol. 8, No. 2

Litzenberger, and Ramaswamy. 1982. The effect of dividend on common stock prices: Tax effect or information effect. Journal of Finance XXXVII: 429

Menyah, K. 1993. Ex-dividend equity pricing under UK tax regimes. Journal of Business Finance and Accounting 20 (1).

Miller, M. H., and K. Rock. 1985. Dividend policy under asymmetric information. Journal of Finance 40: 1031.

Miller, M. H., and F. Modigliani. 1961. Dividend policy, growth, and the valuation of shares. Journal of Business XXXIV (4): 411- 433.

Miller, M. H., and M. S. Scholes. 1982. Dividends and taxes: Some empirical evidence. Journal of Political Economy 90: 1118-1141.

Patell, J. M. 1976. Corporate forecasts of earnings per share and stock price behaviour: Empirical tests. Journal of Accounting Research 14 (2): 246-276.

Penman, S. H. 1983. The predictive content of earnings forecasts and dividends. Journal of Finance XXXVIII (4): 1181-1199.

Pettit, R R. 1972. Dividend announcements, security performance, and capital market efficiency. Journal of Finance XXVII (5).

Pettit R. R. 1977. Taxes, transaction cost and clientele effect of dividend. Journal of Financial Economics: 419.

Poterba, J., and L. H. Summer. 1984. New evidence that taxes affect the valuation of dividends. Journal of Finance: 1397-1415.

Poterba, J. M. 1987. Tax policy and corporate saving. Brookings Papers on Economic Activity 2: 455-503.

Riding, A. L. 1984. The information content of dividends: An other test. Journal of Business Finance and Accounting 11 (2): 163-176.

Ridgway, P. 1997. Imputation system - born 1973; died 3 July 1997 RIP? Taxation 139 (3614): 390.

Robin, A. J. 1991. The impact of the 1986 tax reform act on ex-dividend day returns. Journal of Financial Management Association 20 (1): 60-70.

Ross, S. A. 1989. Information and volatility: no-arbitrage martingle approach to timing and resolution irrelevancy. Journal of Finance 44: 1-17.

Rozeff, M. S. 1982. Growth, beta and agency cost as determinants of dividend payout ratios. Journal of Financial Research: 249-259.

Ryan, T. M. 1974. Dividend policy and market valuation in British industry. Journal of Business Finance and Accounting 1(3): 415-428.

Shefrin, H., and Statman. 1984. Explaining investor preference for cash dividend. Journal of. Financial Economics 13 (2): 253-282.

Stoll, H. R., and R. E. Whaley. 1983. Transaction costs and the small firm effect. Journal of Financial Economics: 57-79.

Strong, N. 1992. Modelling abnormal returns: A review article. Journal of Business Finance and Accounting 19 (4): 533-553. 
Basuki-The Impact of the Abolition of Tax Credit on ...

Tingley, K.R. 1999. Income tax guide 1999-2000. Daily Mail. Orion Business Book. Watts, R. 1973. The information content of dividends. Journal of Business 46: 191-211. Woolridge, J. R. 1983. Dividend changes and securityprices. Journal of Finance XXXVIII (5): $1607-1615$.

Yadav, P. K. 1992. Event studies based on volatility of returns and trading volume: A review. British Accounting Review 24: 157-184. 